\title{
Correction to: Military Identity and the Transition into Civilian Life
}

\section{Correction to:}

K. M. Wilson-Smith and P. J. Corr, Military Identity and the Transition into Civilian Life, https://doi.org/10.1007/978-3-030-12338-3

The original version of the book was inadvertently published without incorporating some of the corrections provided by the co-author, which have been now incorporated. This correction to book has been updated with the changes.

The updated version of the book can be found at https://doi.org/10.1007/978-3-030-12338-3

(C) The Author(s) 2019

K. M. Wilson-Smith and P. J. Corr, Military Identity and the Transition into Civilian Life, https://doi.org/10.1007/978-3-030-12338-3_9 